populacji wskazywać może na całkowitą klęskę systemu Demokratycznej Kampuczy. Klęska ta prócz oczywistego wymiaru etycznego, ma także swój wymiar demograficzny - porażki planów zbudowania wielkiej i ludnej Kambodży. Szczególnego znaczenia w tym świetle nabierają słowa Pol Pota: „...nasza polityka wzrostu populacyjnego odniosła pierwszy znaczący sukces. Na przestrzeni roku urodziło sie 392,000 nowych obywateli... tym samym przekroczyliśmy stan przedwojenny... Musimy przywiązywać wielką wagę do podnoszenia warunków życia i zdrowotności, aby przyspieszyć wzrost naszego narodu..."29.

Klęska rewolucji Czerwonych Khmerów jest faktem bezspornym takim samym faktem jest ogrom ofiar eksperymentu rozwojowego, przeprowadzonego w Kampuczy. Jego jednoznaczna moralnie ocena pozostanie niezmienna, niezależnie od tego czy spojrzymy nań przez pryzmat dziesiątków tysięcy czy też milionów straconych istnień ludzkich. Chcę wszakże zwrócić uwage na fakt, że to fala publicystycznego zainteresowania zbrodnią i śmiercią ofiar rządów Czerwonych Khmerów, obfitująca we wszelkiego rodzaju sensacyjne publikacje, ukształtowała wizerunek kraju w oczach światowej opinii publicznej. Wizerunek ten okazał się być na tyle sugestywny, że na trwałe uformował spojrzenie na ten niezwykle złożony problem przez autorów wywodzących sie nierzadko $\mathrm{z}$ poważnych ośrodków naukowych, którzy poszli drogą wytyczoną przez ich publicystycznych prekursorów.

${ }^{29}$ FBIS, 2 października 1978

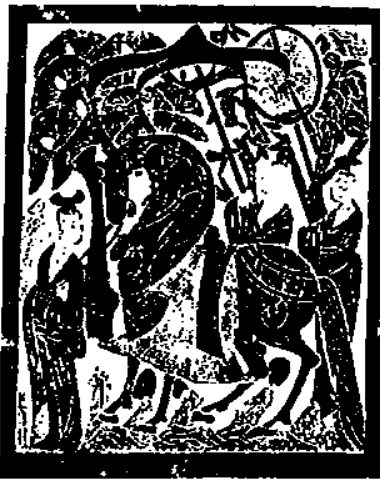

Nguyen Thanh Giang

\title{
OBRAZ WIETNAMSKIEJ REFORMY ROLNEJ W LATACH 1980-1995
}

\section{Kilka słów o historil}

Wietnam jest krajem typowo rolniczym, około $72 \%$ ludności zajmuje sie rolnictwem. Od pierwszych dni powstania państwa wietnamskiego potożenie chłopów i wysokość plonów ryżu najważniejszego produktu rolnego kraju zajmowały ważne miejsce w rozważaniach politycznych władzy. Juz w XI w. wraz z procesem unifikacji terytorialnej i przyjęciem wzorów konfucjańskich potrzebnych do budowy hierarchii urzędniczej, dynastia Ly (1010-1225) wydała pierwsze akty prawne regulujące stosunki własnościowe w zarządzeniu gruntami rolnymi. Proces ten kontynuowano za panowania dynastii Tran (1225-1400). Pod względem formy własności grunty rolne za Ly i Tran były podzielone na: grunty państwowe cong dien, grunty nadane arystokracji thai ap, grunty będące własnością wspólnoty wiejskiej $x a$ i grunty prywatne $t_{u}$ dien $^{1}$.

Grunty państwowe znajdowały się głównie w regionach nowo zasiedlonych i były w znacznym stopniu zagospodarowane przez państwo rękoma jeńców i skazanych ${ }^{2}$. Natomiast członkowie wspólnoty wiejskiej, podstajeńców i skazanych ${ }^{2}$. Natomiast członkowie wspónoty wiejskiej, podstaczali podatek na rzecz dworu. W odróżnieniu od szlachty europejskiej arystokraci wietnamscy mogli się cieszyć tylko tytułem posiadania gruntów typu thai ap. Grunty te należały do króla, który mógł je odebrać i rozdzielić ponownie pomiędzy spadkobierców po śmierci posiadacza. To oczywiście nie wykluczało możliwości posiadania przez szlachtę ziemi prywat-

${ }^{1}$ Nguyen Khac Vien, Vietnam, une longue histoire, Hanoi: The Gioi Publishers, 1993, s. 32.

2 Olszewski W, Historia Wietnamu, Wrocław: Ossolineum, 1991, s. 76. 
nej, szczególnie za panowania Tran'ów, kiedy ta klasa znacznie rozszerzyła swoją władzę ekonomiczną, w tym posiadanie gruntów rolnych, nieraz na niekorzyść wspólnot wiejskich lub indywidualnych chłopów.

W porównaniu z okresem 1400-1800 r. arystokracja wprawdzie posiadała dość wiele ziemi, ale własność prywatna już była respektowana przez państwo i regulowana dekretem wydanym przez władców $z$ dynastii $L y$ uznającym prawo nabywania i sprzedawania ziemi, co przyczyniło się do powstania klasy chłopów - indywidualnych właścicieli ${ }^{3}$

Feudalni władcy szczególną uwagę zwracali na produkcję ryżu. Wiosną każdego roku królowie rozpoczynali ceremonię orania ziemi na symbolicznym ryżowisku aby oddać hołd Patronowi rolnictwa Than Nong. Co więcej, system nawadniania ryżowisk na północy kraju, niezbędny. Co funkcjonowania rolnictwa, był pod szczególną opieką władzy. Prowadzona na wielką skalę mobilizacja ludności do naprawy i umocnienia tam rzecznych lub budowy nowych kanałów zapisała sie w historii jak tradycja zapoczątkowana przez władców Ly i Tran; budowa kanału Lanh Kinh w 1089 r., Lam w 1050 r., tamy Co Xa w 1108 r., kanału Thien Duc w 1309 r. Praktyka ta była kontynuowana przez dynastie Le (1430-1790) i Nguyen (1802-1897)4. Tego rodzaju praca publiczna jest również uważana przez niektórych historyków za jeden $\mathrm{z}$ czynników utrzymujących jedność narodu wietnamskiego.

Ogólnie rzecz biorąc, aż do utraty niepodległości w ostatnich dekadach XIX w., polityka rolna wietnamskich królów polegała na państwowym patronacie nad utrzymywaniem systemu hydrotechnicza panstwowym cy urzędów w tym celu utworzonych) u ulotechnicznego (przy pomoproduktów rolnych i ich ściąganiu oraz redystrybucii w ra podatków od w przypadku kleski ich sciąganiu oraz redystrybucji w ramach pomocy w przypadku klęski żywiołowej. Stosunek własności gruntowej miał inny charakter niż w Europie, co wynika $z$ odmiennej pozycji monarchy. Jako jedyny prawomocny właściciel ziemi monarcha wydzierżawiał ja członkom klasy arystokratycznej i wspólnotom wiejskim, które odgrywały najważniejszą rolę w gospodarce. Nie oznaczało to, że dwór nie był zainteresowany sytuacją istniejąca wewnątrz wspólnot wiejskich. Wraz z rozbudowaniem aparatu biurokratycznego, promowaniem neokonfucjańskich ideologii zapożyczonych od chińskiej dynastii Ming, wprowadzeniem sytemu fiskalnego, standardyzacją miar i wag za panowania dynastii Le (1430-1791), wsparcie rozwoju rolnictwa stanowiło jedno $z$ centralnych zadań państwa. Rozwój ten dał impuls procesom urbanizacji, przyczynił się do rozkwitu handlu, wzrostu demograficznego i sprzyjał ekspansji te-

\footnotetext{
3 Nguyen Khac Vien, 1993, op.cit., s. 33.
'Tamże, s. 35.
}

rytorialnej na południe kraju ${ }^{5}$. Jednak struktura społeczna wspólnot wiejskich pozostała nienaruszona do początku XX w.

Komunistyczna Partia Wietnamu (KPW), założona w 1930 r., od pierwszych dni swej działalności upatrywała w chłopstwie ważnego sojusznika proletariatu $\mathrm{w}$ rewolucji. Obalenie kolonialno-feudalnego panowania i przeprowadzenie reformy rolnej znalazły się w programie KPW tuż po pryncypialnym celu rewolucji, jakim było odzyskanie niepodległości. Zgodnie z ideologia marksistowsko-leninowską uznano, że robotnicy mają być siła przewodnia rewolucji ze względu na ich położenie społeczne i misję historyczna. Jednak z powodu małej liczby proletariuszy (wynosiła ona historyczną. Jednak z powodu maiej licź́ 220 tys. w 1929 r. na 20 mln mieszkańcó Indochin'), większość członków KPW niższego szczebla rekrutowano spośród chłopów. Pierwszą próbe zrealizowania programu przekształcenia społeczeństwa kolonialno-feudalnego $\mathrm{w}$ socjalistyczne wykonano również $\mathrm{w}$ wiejskim regionie prowincji Nghe An i Ha Tinh, gdzie latem $1930 \mathrm{r}$. utworzono na wzór radziecki rady rewolucyjne tzw. xo viet nghe-tinh, krwawo sthumione i spacyfikowane przez kolonizatora w rok później.

W latach 50-ych na terenach kilku świeżo wyzwolonych prowincji północnych, władza Demokratycznej Republiki Wietnamu (DRW) zaczęła wprowadzać w życie reformę rolną cai cach ruong dat, która objęła później cały kraj. Celem pierwszej fazy reformy było uzyskanie zaufania chłopów do partii, co mogłoby zachęcić młodych mężczyzn do wstąpienia do wojska ludowego. W istocie reforma polegała na klasyfikowaniu powierzchni gruntów i kategorii właścicieli w celu stopniowego likwidowania własności prywatnej. Bogaci chłopi uznani za obszarników (element reakcyjny wobec sprawy rewolucyjnej) zostali rozstrzelani po wydaniu wyroków przez sądy ludowe. Podobny los spotkał wielu średnio zamożnych chłopów, ponieważ procedurę kwalifikacyjną prowadzono bez respektowania zasady praworządności. Ich ziemie oddano w ręce grup roboczych tzw. doi cai-cach utworzonych i wysłanych $\mathrm{z}$ centrali w teren w celu przeprowadzenia reformy. Grupy robocze, w skład których wchodzili głównie żołnierze przeszkoleni na kursach indoktrynacji maoistowskiej miały prawo rozdzielać ziemię odebraną obszarnikom wśród najbiedniejszych lub bezrolnych chłopów. W sumie zabrano bez odszkodowania 810 tys. ha ziemi uprawnej i rozdzielono ją wśród 2104 tys. rodzin chłopskich $^{7}$.

${ }^{5}$ Whitmore K. J., Literati culture in Dai Viet 1430-1840, Modern Asian Studies, 1997, vol. 31 , nr 3, s. 669 .

6 Olszewski, 1991, op.cit., s. 289

${ }^{7}$ Góralski W., Socjalistyczna Republika Wietnamu [w:] Dzieje państw socjalistycznych. Gospodarka, spoteczeństwo, polityka, Warszawa: Państwowe Wydawnictwo Ekonomiczne, 1987, s. 238. 
Reforma rolna w latach 50-tych obaliła całkowicie stary porządek w społecznościach wiejskich, zmieniając tradycyjny system wartości, a często i więzi rodzinne. Pomimo gestu przyznania się do „błędów” popełnionych w tym okresie, KPW przystąpiła do następnej fazy reformy już w 1955 roku. Polegała ona na masowej kolektywizacji ziemi i środków produkcji, głównie bydła i narzędzi do pracy oraz na przymusowym organizowaniu spółdzielni produkcyjnych tzw. hop-tac-xa.

\section{Kolektywizacja rolnictwa i jej konsekwencje}

Oprócz względów czysto ideologicznych kolektywizacja służyła państwu do administracyjnego przebudowania społeczności wiejskiej - pierwszy raz na wielką skalę w historii Wietnamu. Umożliwiała też kontrolowanie produkcji rolnej, będącej bazą ekonomiczną dla procesu industrializacji, i mobilizowanie sił ludzkich do operacji militarnych i paramilitarnych w wojnie. Kolektywizacja wg oficjalnej propagandy miała na celu modernizację w szybkim tempie zacofanego wietnamskiego rolnictwa, podniesienie go na poziom krajów socjalistycznych takich jak ChRL i ZSSR. Jednak warunki materialne i społeczne - rozdrobnienie terenu, zacofany stan techniczny, wojna z Republiką Wietnamu i USA, nie pozwoliły na budowanie zbyt wielu gospodarstw rolnych o znacznej wielkości, takich jak w innych krajach bloku socjalistycznego. Do końca lat 60 -ych zdołano zorganizować tylko 44 takie gospodarstwa specjalizujące się $\mathrm{w}$ uprawie roślin technicznych i hodowli bydła w regionach poza deltą Rzeki Czerwonej ${ }^{8}$. Dlatego program reformy i kolektywizacji ograniczał się głównie do przekształcania wspólnoty wiejskiej w spółdzielnię produkcyjną. Dostrzegając trudności natury technicznej, oraz wynikające ze różnicowania etnicznego i ekonomicznego regionów kraju, władza dokonywała kolektywizacji stopniowo, bacząc na reakcję chłopów. Towarzyszyła jej wieloletnia kampania propagandowa powołująca się $\mathrm{z}$ jednej strony na sukcesy w innych państwach socjalistycznych, a $z$ drugiej odwołująca się do patrio-
tyzmu.

Jeżeli reforma rolna w latach 1953-1956 rozdzieliła grunty rolne mniej więcej równo między chłopów, to kolektywizacja czyniła $\mathrm{z}$ wszystkich gruntów, $w$ tym rolnych, jednolity rodzaj zwany ziemią należącą do całego ludu. To był pierwszy krok, który zniósł własność prywatną, sankcjo- nując tym samym prawo władz do podziału gruntów. Następnym krokiem była reorganizacja stosunków pracy i utworzenie spółdzielni produkcyjnych. Najpierw zachęcano do porzucenia pracy indywidualnej lub rodzinnej na rzecz pracy w ramach małej grupy składającej się z kilku rodzin w jednym sąsiedztwie tzw. to doi cong (grupa wymiany pracy). Po pewnym czasie organizowano spółdzielnię produkcyjną, w skład której wchodziło kilka „grup wymiany pracy”. Zazwyczaj jedna spółdzielnia obejmowała wszystkie rodziny w jednej wiosce (thon). Kilka spółdzielni tworzyło jedną komunę wiejską $x a$ - odpowiednik gminy wiejskiej w Polsce, która równocześnie była jednostką najniższego szczebla w strukturze administracyjnej państwa. Posiadała ona podwójny aparat rządzenia: komitet partyjny i radę komunalną wybieraną przez partyjnych reprezentantów. Większa liczba komun wiejskich wchodziła w skład powiatu huyen, a kilka do kilkunastu powiatów tworzyło prowincję tinh. Proces ten następował stopniowo. Np. w roku 1957 chłopi w komunie Binh Minh (powiat Thanh Oai, prowincja Ha Tay) utworzyli kilka grup wymiany pracy, każda z nich objęła od dwóch do trzech rodzin. W latach 1959-61 przystąpili do zorganizowania spółdzielni produkcyjnej, skupiającej po 10 rodzin w jednym sąsiedztwie. Cała komuna odtąd miała 10 spółdzielni. W połowie lat 60-ych władza zmniejszyła liczbę spółdzieni z 10 do 3 . Dopiero w połowie lat 70-ych dołączono je do jeszcze większej spółdzielni-komuny majacej pod kontrolą ok. 400 ha ziemi i 2000 rodzin.

Własność gruntu i narzędzi pracy też uległa konsolidacji w ramach spółdzielni i komuny wiejskiej. Każda spółdzielnia oprócz bydła i narzędzi pracy kontrolowała ziemię uprawną i publiczną na swoim terenie, w tym grunty rolne, użytkowe i kanały irygacyjne. Do jej funkcji należał także nadzór nad produkcją i dystrybucja zbiorów po odliczeniu kwot podatkowych. Każdemu członkowi spółdzielni przydzielono określoną rolę w produkcji, liczbę bydła i zestaw narzędzi. Pracował on według sytemu punktów, na podstawie którego dostawał porcję żywności.

Wydawało się, że kolektywizacja osiągnęła szczyt w połowie lat 60-ych. W całym kraju było ok. 40.000 spółdzielni produkcyjnych, obejmujących 86\% ludności wiejskiej. Jednak spółdzielnie lat 60 -ych miały stosunkowo niewielkie rozmiary. W ich skład wchodziły najczęściej rodziny, lineaże wiejskie lub osoby $\mathrm{z}$ sąsiedztwa. Natomiast w latach 70 -ych charakter rodzinny spółdzielni uległ radykalnej zmianie wskutek ich konsolidacji. Z 40.000 małych spółdzielni zrobiono 19.000 , powiększono liczbę urzędników administracyjnych $i$ partyjnych poprzez rozbudowanie $z$ rozmachem aparatu biurokratycznego. W tym czasie już prawie 95\% ludności wsi pracowało $\mathrm{w}$ spółdzielniach produkcyjnych ale proces konsolidacji nie zatrzymał się na tym etapie. Do zakończenia kolektywizacji w 1980 r. na Północy Wietnamu powiększono jeszcze bardziej rozmiary spółdzielni, 
redukując ich liczbę do $12.000^{9}$. Paradoksalnie, im większy był rozmia organizacyjny spółdzielni tym bardziej malała efektywność produkcji. Od czasu, gdy praca na polu utraciła charakter wzajemnej pomocy w rodzinie, rodzie czy sąsiedztwie, nastroje wśród chłopów uległy negatywne zmianie. Praca w anonimowym zespole za puntopów uległy negatywnej zakaz wymiany produktów rolny ły do aktywności i pomysłowlnych na tradycyjnych bazarach, zniechęcaczyje”, uległy degradacii. innych zajęć związanych $\mathrm{z}$ rzemiosłów uciekło $\mathrm{z}$ pracy w spółdzielni do Napięcie na wsi rosło wskutzemiosłem, drobnym handlem czy usługami. capita za wskánik wskutek nieurodzaju i głodu. Biorąc porcję ryżu per dek produkcji towarzysyości produkcyjnej, wyraźnie było widać, że spalat 60-ych do końca lat 80 intensyfikacji procesu kolektywizacyjnego od wyniosła $318 \mathrm{~kg}$ ryżu, $295 \mathrm{~kg}$. W $1961 \mathrm{r}$. statystyczna porcja na osobe w $1980 \mathrm{r}^{10} \mathrm{~kg}$ ryżu, $295 \mathrm{~kg}$ w $1970 \mathrm{r}$. $247 \mathrm{~kg} \mathrm{w} 1976 \mathrm{r}$. i tylko $215 \mathrm{~kg}$

Po zjednoczeniu kraju w 1975 r., na południu Wietnamu kierownictwo słowych i plantacji głó na nacjonalizację wielkich przedsiębiorstw przemyProgram ten, okrón miał być realizowany szybko i następny etap $\mathrm{w}$ rewolucji wietnamskiej, handel, a na wsi i w regko i zdecydowanie. W miastach upaństwowiono spodarstw pá i 9300 różnych grup wzajemn truong, 1300 spółdzielni produkcyjnych darstw chłopskich. Trzeba dom pomocy, obejmujących ok. 36\% gospostwowe gospodarstwa rolne, dodac, ze te nowo utworzone na południu pańspecjalizowały sie w uprawie rós podobne jednostki na Północy, równiez 1976-1977 dochód W uprowe roslin technicznych na eksport. W latach niej Republiki Wietnamu, ale wyniki $17 \%$ dzięki przejęciu Południa, dawżywności wzrosła tylko o $10 \%$ wyniki w rolnictwie były słabe, produkcja do 10040 tys. ton 1978 , zbiory ryżu spadły z $12 \mathrm{mln}$ ton w $1976 \mathrm{r}$

\section{Początek reformy}

Pierwszy krok w reformie rolnictwa podjęto pod koniec lat 70-ych pod presją fatalnej sytuacji w tym sektorze, co przyczyniło się do braku pro-

9 Tria Kerkwliet

tics on decollectivization, The effects of everyday poli-

${ }^{10}$ Tamże, s. 403.

${ }^{11}$ Goralski, 1987, op.cit., s. 255. duktów rolnych i towarów konsumpcyjnych na rynku krajowym. Dało to początek szerszym przemianom systemowym w Wietnamie, które są kontynuowane do dnia dzisiejszego $\mathrm{z}$ mniejszym lub większym oporem natury ideologicznej. Wprawdzie polityka odnowy Doi Moi została oficjalnie zadeklarowana na VI Zjeździe KPW w $1986 \mathrm{r}$., ale zmiany w rolnictwie miały wcześniejszy poczattek. Już w 1979 r. KC KPW na VI posiedzeniu plenarnym przyjął rezolucję „Kierunek i zadania w rozwoju produkcji dóbr konsumpcyjnych i przemysłu lokalnego" ${ }^{2}$. Jej celem było podniesienie produkcji w rolnictwie i zmniejszenie napięcia na wsi. Rok później Rada Ministrów pozwoliła członkom spółdzielni produkcyjnych uprawiać indywidualnie grunty opuszczone przez spółdzielnie i hodować bydło na sprzedaż. W styczniu $1981 \mathrm{r}$. KC KPW dyrektywa $\mathrm{nr} 100^{13}$ upoważnił władze spółdzielni do rozdzielenia gruntów rolnych pomiędzy członków i podpisywania z nimi kontraktu produkcyjnego, na mocy którego, po odliczeniu tzw. kwoty kontraktowej, mogli oni zatrzymać dla siebie plony i sprzedać je na rynku lokalnym. W rzeczywistości Dyrektywa ta umożliwiła wydzierżawienie ziemi uprawnej i środków produkcji, będących dotychczas w rękach spółdzielni. Rolnicy mogli dysponować narzędziami i swobodnie planować pracę i zasiewy w polu. Zobowiązano ich jedynie do uiszczenia podatków rolnych i czynszu na rzecz spółdzielni. Ta ze swojej strony miała zapewnić dostawę nawozów, transport zbiorów, naprawę systemu irygacyjnego na dużą skalę etc. Jej praca była nadzorowana przez partyjnopaństwową administrację powiatu i prowincji.

Sytem kontraktowy khoan san pham miał być stosowany wobec chłopów indywidualnych i grup wzajemnej pomocy (w niektórych regionach byli członkowie spółdzielni wciąz pracowali w ramach grup wzajemnej pomocy organizowanych $\mathrm{z}$ własnej inicjatywy). Oficjalnie spółdzielnie produkcyjne nie zostały rozwiązane, a część z nich nadal funkcjonowała w sposób kolektywistyczny. Początkowy efekt nowego sposobu organizacji pracy w rolnictwie był zachęcający, ale jeszcze ograniczony. Powodów tego było wiele, jak np. brak funduszów na inwestowanie w produkcję, zła dystrybucja nawozów i środków produkcyjnych dużej wielkości (maszyny, traktory), będących wciąż w posiadaniu spółdzielni itp. Nadmiernie rozbudowana kadra partyjno-administracyjna w dużym stopniu obciażyła rolnictwo. Sytuacja wymagała radykalniejszego kroku na drodze reformowania rolnictwa, jak i całego systemu polityczno-ekonomicznego państwa.

${ }_{12}$ Bui Duc Tuyen, Viet Nam. Tu lieu kinh te bay nuoc thanh vien ASEAN (Dane ekonomiczne siedmiu państw członkowskich ASEAN), Hanoi: Nha xuat ban thong Ke, 1996 , s. 326.

${ }_{13}$ Nguyen Phu Trong. red., Vietnam from 1986, Hanoi: The Gioi Publishers, 1995, s. 30,31 . 


\section{Polityka odnowy}

繁 Na ralnym Nguyen Van Linh, oficjalnie zadeklarowała politykę odnowy tzw. Doi Moi, która podkreśliła nie tylko konieczność zmian w sektorze rolniczym, ale także w sferze ideologicznej, polityce kadrowej, zagranicznej i całym systemie partyjno-administracyjnym. Nie ominęła też ona przemysłu i sektora usługowego, uważanego dotychczas za nieważny w gospodarce socjalistycznej. Kierownictwo KPW przyznało się do popełnienia „pewnych błędów w polityce rolnej, w tym masowej kolektywizacji dokonanej na siłę, lekceważenia znaczenia gospodarstwa rodzinnego i prywatnych producentów". Partia próbowała uzasadnić nową linię polityki, powołując się na dostosowanie doktryny marksistowsko-leninowskiej do nowych warunków budowy socjalizmu.

De facto polityka Doi-Moi polega na dekolektywizacji sektora rolnego z cichą akceptacją indywidualnego użytkowania gruntów uprawnych W rolnictwie i przemyśle rola państwa wciąż dominuje, ale ,indywidualni producenci nie powinni być dyskryminowani, ani zmuszeni do wstąpienia do spółdzielni, a członkowie spółdzielni produkcyjnych mogą rezygno wać $z$ członkostwa w sposób dobrowolny"14. Poza tym polityka Doi-Moi uznała różnorodność branży produkcyjnych w rolnictwie, usunęła bariery administracyjno-prawne w obrocie towarowym, w tym produktów rolnych między prowincjami i regionami. Względem polityki finansowo-monetarnej zapoczątkowała ona stopniową liberalizację cen, oznaczająca przechodzenie od regulacji opartych na dwóch cenach, państwowej dla sfery budżetowej i odrębnej rynkowej, do systemu jednocenowego w gospodarce. Najpierw uznano cenę rynkową za legalną przy zachowaniu cen państwowych stosowanych wobec przedsiębiorstw państwowych, żeby później zaakceptować już tylko jedną cenę rynkową. $\mathrm{Z}$ dokumentów KC KPW z tego okresu wynika, że partia uznała stosunek popyt-podaż i zgodność ceny $z$ wartością nabywczą towaru. Doszła do głosu także koncepcja "gospodarki mieszanej, wieloelementowej" z zezwoleniem na utworzenie przedsiębiorstw prywatnych średniej wielkości i coraz mniej regulowanym rynkiem wewnętrznym. Ostatecznie ta koncepcja znalazła sie w zapisie Konstytucji 1992 r., definiującym charakter gospodarki Wietnamu.

Po wprowadzeniu w życie dyrektywy nr $100 \mathrm{i}$ systemu kontraktu, produkcja rolna odnotowała lepsze rezultaty. Jednak mechanizm funkcjonowania całej gospodarki w skali makro wciąż pozostał scentralizowany, co ograniczyło wzrost produkcji. W tej sytuacji, w kwietniu 1988 r., Biuro Polityczne KC KPW przyjęło Rozporządzenie nr 10 o rolnictwie. Partia przyznała spółdzielniom produkcyjnym samodzielność $\mathrm{w}$ podejmowaniu decyzji o planowaniu produkcji i zgodziła się na różne formy posiadania ziemi, środków produkcji w spółdzielni i poza nią. Nieoficjalnie rozporządzenie to uznało „ograniczona własność indywidualna”. Natomiast słowo „prywatne” z powodu złego skojarzenia nie znalazło się w jego tekście. Generalnie rzecz biorąc rozporządzenie — jeden z najważniejszych aktów prawnych z okresu odnowy - zniosło scentralizowana metode zarządzania $w$ rolnictwie, oddając inicjatywę w ręce władz lokalnych ${ }^{15}$.

Dzięki polityce Doi-Moi produkcja żywności wzrastała szybko: z 17,5 mln ton w 1987 r. do 20,5 mln w 1989 r. Jeżeli w 1988 r. Wietnam jeszcze importował 450 tys. ton ryżu, to w rok później stał się jednym z eksporterów tego produktu. Wzrost ten utrzymywał się $\mathrm{w}$ następnych latach (19 225 tys. ton ryżu, 2367 tys. ton produktów innego rodzaju w 1991 r., i odpowiednio 21590 tys. i 2624 tys. w 1992 r., 22836 tys. i 2665 tys. w 1993 r., 23528 tys. i 2670 tys. w 1994 r. $^{16}$ ).

W następnej fazie odnowy państwo zniosło przymusową dostawę produktów rolnych, nałożoną wcześniej na spółdzielnie, i zaczęło wprowadzać podatek rolny. Ministerstwo Finansów miało ustalić ceny produktów rolnych (np. 1000 VND za $1 \mathrm{~kg}$ ryżu w 1994 r.; VND - waluta wietnamska, dong)), na podstawie których władza płaci za kwotę opodatkowaną. Uiszczenie podatku rolnego upoważnia producenta do kupna od państwa nawozów i innych środków pomocniczych, najczęściej importowanych. O stopniu liberalizacji w rolnictwie świadczy fakt, że powstał wolny rynek zboża i bydła, na którym nielegalny eksport ryżu sięgnał 600 tys. ton w 1995 r. $^{17}$

\section{Zmiany instytucjonalne towarzyszące reformie roinej w latach 1980-1995}

a. Sektor finansowy

Liberalizacja cen wywarła ogromny wpływ na wzrost produkcji rolnej. Przed 1986 r. na rynku funkcjonował mechanizm dwucenowy, w którym ceny rynkowe zazwyczaj były wyższe niż państwowe. Dla przykładu na

\footnotetext{
${ }^{15}$ Dokumenty wydawane przez KC KPW mają moc wiążąca wobec administracji państwowej.

${ }^{16}$ Nguyen Phu Trong. red, Vietnam from 1986, Hanoi: The Gioi Publishers, 1995, s. 30,31 .
}

${ }^{17}$ Dien Dan-Forum Magazine, (Bourg-La-Reine), 1996, nr 46, s. 7. 
czarnym rynku $1 \mathrm{~kg}$ ryżu kosztował 10 VND i tylko 6 VND w sklepie $\mathrm{z}$ towarami na kartki, gdzie pracownicy sfery budżetowej mogli kupić artypracowników, poniewaź niska pensja na niekorzyść tych na czarnym rynku, a pozwoliła im na częste zakupy ṫ czarnym rynku, a dostawy do sklepów państwowych były niewielkie Zeby rozwiązać ten problem po usunięciu systemu podwójnych cen, państwo zdecydowało się na podniesienie pensji w sferze budżetowej, jednocześnie wprowadzając więcej pieniędzy do obiegu, starając się utrzymać relację cena-pensja na „rozsądnym poziomie”. Nazwano to „polityka cen pensji i pieniądza" chinh sach gia, luong, tien, realizowana przez Rade Ministrów ${ }^{18}$. Pierwszą reakcją rynku była inflacja i dewaluacja VND. W ciągu trzech lat, od 1986 do $1988 \mathrm{r}$. hiperinflacja osiagnęła poziom od 300 do $500 \%$ rocznie. Życie wielu rodzin ze sfery budżetowej i mieszkańców miast pogorszyło się, ale w rolnictwie nie odnotowano spadku produkcji. Przeciwnie, indywidualni rolnicy zyskali na sprzedaży żywności. Co ciekawe, jednym z powodów minimalnego oddziaływania polityki pensji i pieniądza" na produkcję rolną jest jej niski poziom techniczny. Wzrost ceny paliwa wskutek inflacji nie wpłynął na działalność produkcyjną, ponieważ traktory i ciągniki były mało popularne w użytku. Niemniej jednak inflacja doprowadziła do napięcia w miastach i wśród pracowników sektora publicznego, emerytów i rencistów, co wymusiło na kierownictwie konieczność szybszego przeprowadzenia reformy.

W październiku 1987 r. rząd zaakceptował kurs waluty narodowej zbliżony do kursu rynkowego: 18 VND/1USD, a od lipca 1988 r. rozpocza reformę systemu bankowego. Banki komercyjne od ca 1988 r. rozpoczą nie od Banku Centralnego, kredyty udzielone prze te pierwz. zaczeły jedal priąz były one w rękach państwa zaczęły jednak przestrzegać reguł rynku. Początkowym kapitałem, włożonym przez Bank Centralny, musiały one obracać na własną odpowiedzialność, operując odsetkami aby zachęcić ludność do lokowania w nich oszczędności. W stosunku do przedsiębiorstw państwowych banki stosowały zasadę udzielania kredytu, nie zaś fundowania pożyczek bez pokrycia tak jak w okresie poprzednim. Zniesiono zakaz handlu złotem i ka mieniami szlachetnymi. Nowopowstające firmy prywatne mogły także brać kredyty z banku. Nowa polityka finansowa, w pewnym stopniu przypominająca polską terapię szokową Balcerowicza, spowodowała początkowo ogromny wzrost cen towarów konsumpcyjnych: $774,7 \%$ w $1986 \mathrm{r}$., $223,1 \%$ w 1987 r. i $393,8 \%$ w 1988 r. ${ }^{19}$. Nie była to jednak tendencja ciagła.

\footnotetext{
${ }^{18}$ Elliot D.W.P, Vietnam faces the future, Current History, $1995 \mathrm{nr} 12, \mathrm{s.} 412-419$
Bui Duc Tuyen, 1996 , op.cit.
}

Od 1989 r. wzrost cen spowolnił się do $34,7 \%$, w 1990 do $67,4 \%$, w 1991 r. $67,6 \%$, w 1992 r. do $17,2 \%$, a ostatecznie reforma sektora finansowego w dużym stopniu zapewniła Wietnamowi stabilność ekonomiczną do dnia dzisiejszego.

\section{b. Inwestycje a reforma rolnictwa}

Następnym etapem reformy były inwestycje $\mathrm{w}$ infrastrukturę rolnictwa. Dekolektywizacja i liberalizacja polityki rolnej nie wystarczyły, żeby modernizować ten sektor uważany za najbardziej zacofany w gospodarce narodowej. Można powiedzieć, że wraz $\mathrm{z}$ otwarciem kraju na świat i reorientacją polityki zagranicznej po upadku ZSRR ku państwom Azji Wschodniej i ASEAN'u, kierownictwo KPW uświadomiło sobie, że pokonanie głodu na wsi było dopiero początkiem modernizacji kraju oraz przyszłej produkcji rolniczych nadwyżek eksportowych. Zanim rząd podjął decyzję o dokapitalizowaniu rolnictwa, chłopi rozpoczęli na własną rękę organizować fundusz wspierania produkcji. Jednak z powodu braku doświadczenia $w$ zarządzaniu ta prywatna kampania poniosła klęskę: od 1990 r. odnotowano upadek 6 tys. tego rodzaju funduszy, co zmusiło rząd do aktywniejszego działania ${ }^{20}$. Utworzono zatem w 13 prowincjach fundusze inwestycyjne na wzór państw ASEAN, aby wspierać produkcje rolną. Miały one gwarancję rządową. Kilka lat później, w 1995 r., Bank Centralny wprowadził $w$ życie linie kredytowe przeznaczone dla ubogich rodzin chłopskich, które nie były w stanie realizować planu inwestycyjnego z powodu braku pieniędzy. Jednak działalność tychże funduszy była dośc ograniczona ze względu na ich skromny kapitał. Dlatego rząd liczył na inwestycje zagraniczne, które zaczęły wchodzić do Wietnạmu po przyjęciu przez KPW polityki odnowy.

Niewątpliwie rolnictwo wietnamskie potrzebowało inwestycji zagranicznych. W zasadzie nie powinny to być tylko inwestycje w produkcję ale równiez $\mathrm{w}$ technologię przetwórczą i marketing. Oprócz ryżu Wietnam produkuje kauczuk, herbatę, kawę, trzcinę cukrową, papaty, tytoń i owoce tropikalne. Prawie wszystkie te produkty mogłyby być towarem na eksport. Brak inwestycji zagranicznych był poważną przeszkodą w eksploatacji tego potencjału. Ludzie, choćby pracowici i pomysłowi nie mogli wiele zdziałać. Warto przypomnieć, że po okresie dekolektywizacji mieszkańcy wsi szukali różnych sposobów zarobku, co przyczyniło się m.in. do pojawienia się hodowli jeleni i niedźwiedzi w prowincjach Środkowego Wietnamu. Młode rogi jeleni od zawsze były cennym lekarstwem w medy-

${ }^{20}$ Elliot, 1995, op. cit., s. 412-419. 

cynie tradycyjnej, tak samo było z woreczkiem żółciowym i mięsem nie-
dźwiedzia.

Od 1988 do 1993 r., ok. $6435 \mathrm{mln}$ dolarów inwestycji zagranicznych z Zagranica. Tylko 81 projektó Komitecie ds. Inwestycji i Współpracy nictwa i leśn porównania, inwestycje wne projekty umieszczono w rybołówstwie. Dla jektównania, inwestycje w przemysł wyniosły $2.328 \mathrm{mln}$ dolarów (285 proturystykę i hotelarstwo $1.276 \mathrm{mln}$ ( 86 projektów) ${ }^{21}$

c. Regulacje prawne dotyczące rolnictwa $i$ administracji państwowej

W lipcu $1993 \mathrm{r}$. parlament uchwalił nowe prawo gruntowe, uchylają tym samym ustawę o ziemi i gruntach z 1987 r. Nie było przypadkiem, że nowa ustawa pojawiła się dopiero w rok po $\mathrm{r}$. Nie było przypadkiem, że Socjalistycznej Republiki dopiero w rok po przyjęciu nowej konstytucji w mocy art. 4 mówiacy o Wietnamu. Konstytucja z 1992 r. utrzymała i społeczeństwie. Postepem o przewodniej roli KPW w systemie politycznym prawa. Również prawo, a było uznanie, iż KPW działa odtąd $w$ ramach cjonowania państawo, a nie przemoc rewolucyjna określa zasadę funkustroju SRW, a tego nowe prawo łego ludu i przedmioteme definiuje w art. 1: „Ziemia jest własnością caPaństwo przydziela ziemie i grunty jednotz administrację państwową. dowej, organom administraci, poljty jednostkom gospodarczym, armii luniom, zwanym dalej stowarzi, politycznym i społecznym stowarzyszeosobom pryw dalej stowarzyszeniem, gospodarstwom rodzinnym oraz i długotrwałość" 2 . Z kolei art 20 uzytkowie na zasadzie zapewniającej stabilność ziemi uprawnej na 20 i 50 lat 20 określa długość terminu użytkowania niej sadzanych kowania na prośbe użytkie tego okresu państwo przedłuża termin użytprzedzający użytkownik przika pod warunkiem, że przez cały okres ponych dotyczących ziemi.

Zamiast własności prawo gruntowe z 1993 r. wprowadziło takie pojęcia jak „posiadanie ziemi” i „prawa użytkownika”, odniesione do różyych aktów administrotów, formy i celu zarządzania gruntami. Wydano wiele aktów administracyjno-prawnych, żeby uregulować ten problem. W imie-

1 Nguyen Anh Tuan, Pham Huu Thang, i Hoang Van Huan, Foreign investment in Vietnam, juridical bases, present state, opportunities and Van Huan, Foreign investment in hers, 1994, s. 37.

${ }^{22}$ Selection of fundamental laws and regulations of

shers, 1995, s. 283, 284 . niu państwa organy administracyjne (komitety ludowe) na szczeblu prowincji i miast zostały wyposażone w kompetencje w sprawach dotyczących ziemi jako instancja najwyższa (art. $24,25,29,31$ i inne). W art. 31 ustalono, iż przeniesienie prawa użytkowania gruntów rolnych jest dozwolone, ale za zgodą komitetu ludowego gminy wiejskiej $x a$. Z kolei prawo gruntowe z $1993 \mathrm{r}$. i prawo o inwestycjach zagranicznych z $1987 \mathrm{r}$. pozwalaja inwestorom zagranicznym (osoby prawne i fizyczne) na dzierżawę ziemi do 100 lat.

\section{Skutki ekonomiczno-społeczne reformy rolnej}

Niewątpliwie dekolektywizacja spółdzielni produkcyjnych w sektorze rolniczym i uchwalenie nowych regulacji prawnych, w tym prawa gruntowego z $1993 \mathrm{r}$. dały impuls rozwojowi produkcji rolnej. Wietnam z pozycji importera ryżu stał się jego eksporterem. Oprócz ryżu Wietnam zaczął eksportować inne produkty rolne, np. w 1993 r. 4000 ton herbaty, 20.000 ton kawy i owoce morza o wartości 265 mln dolarów. Jednak biorąc pod uwagę wciąż ogromną liczbę ludności żyjącej z rolnictwa - $72 \%$ populacji — i jego udział w PKB: 40,5\% w 1991 r., 33,9\% w 1992 i $28,7 \%$ w $1994 r^{23}$, można powiedzieć, że ten sektor wymaga jeszcze wiele inwestycji. Brak jasnych regulacji prawnych również jest przeszkodą w modernizacji rolnictwa. Prawo gruntowe z 1993 r. nie rozwiązało tego problemu, unikając uznania własności prywatnej. Chociaż własność niepaństwowa obejmuje praktycznie $95 \%$ w tym sektorze, to nie znaczy, że producenci i rolnicy indywidualni posiadaja pełne prawo własności gruntów. Mało zrobiono by podnieść kompetencje administracji terenowej, której wciąż brakuje kadry odpowiednio wykształconej i zdolnej do funkcjonowania w nowych warunkach. Następnym obciążeniem dla rolnictwa jest ogromna sfera budżetowa. Wskutek wieloletniej wojny liczba osób, którym państwo przyznaje rente - rodziców poległych żołnierzy, inwalidów wojennych - wynosi ok. 3,5 mln. Do tego dochodzi ok. 1,3 mln urzędników administracji, 1,5 mln członków partii, sił zbrojnych i MSW. Jeżeli przyjmie się, że każdy z nich ma na utrzymaniu czteroosobową rodzinę, to liczba osób żyjących na koszt państwa wzrosłaby do $25 \mathrm{mln}$ na $75 \mathrm{mln}$ mieszkańców kraju ${ }^{24}$.

\footnotetext{
${ }^{23}$ Bui Duc Tuyen, 1996, op.cit., s. 362
}

${ }^{24}$ Huynh Xuan, Tien trinh cai cach guong may o Viet Nam (Proces reformowania aparatu administracyjnego w Wietnamie), Dan Chu va Phat Trien, (Iserlohn) 1997, nr 10, s. 35 . 
Po uchwaleniu konstytucji w 1992 r. administracja na szczeblu pro wincji, powiatu i gmin stała się bardziej niezależna od administracji rządowej. W przeciwieństwie do organizacji wewnętrznej KPW, jednolitej administrowani $1992 \mathrm{r}$. komitety ludowe uy ban nhan dan, zajmujące sie i nie podlegaja rzadowi. Prezes przez rady ludowe hoi dong nhan dan, jewody. Sytuacja ta doprowadziła Ministrów nie może odwołać np. wone skutki społeczne. Niezależnó́ć pewnych uchybień, mających poważ-. niższego szczebla, szczególnie we wła petencyjna zezwalała aparatczykom nie rozmaitych podatków chłopów. Od maja do lip i opłat lokalnych, co spotkało się z ostrą reakcja Thai Binh na północy kraju $1997 \mathrm{r}$. tysiące mieszkańców wsi w prowincji ko ok. 30 ro

Ponieważ sprawa własności

ruchomości w miastach pozostaje gionach wiejskich w prowincji Ha Tay, niedaleko stolicy tle do konfliktów. W marcu $1996 \mathrm{r}$ państwo w celu budowy pól stolicy Hanoi, spór o ziemię zabraną przez hudniowo kor broniącymi ziemi a jednostkami krwawe zamieszki między chłopami płaca odszkodowania za zabrani MSW i MON ${ }^{26}$. W zasadzie państwo wydo osób prywatnych jednak prawrunty uprawne czy użytkowe należące do niezadowalajacych rozwian

ących rozwiązań.

$\dot{z} y$ stwierdzić, że dzieki dekormy rolnictwa w okresie 1980-1995 r. naleralizacji cen i polityki rolnej państwa cji spółdzielni produkcyjnych, libenormalności i zaczęło gu ustaw regulujacy się rozwijać. Uchwalenie prawa gruntowego i szereustaw i aktów prawnych w randze uy wospodarce rynkowej - ok. 100 pewniło rolnictwu pewien randze ustawy w okresie 1987-1995 r. - zawoju. Jednak niejasnoẃci kształt prawny niezbędny dla dalszego rozmenedżerów, słabe mete zahamować mojowe i zagraniczne mogą na dłuższa napięcia i konflikty najbliższym czasie rodzić napięcia i konflikty o daleko idących skutkach społeczno-politycznych.

\footnotetext{
${ }^{25}$ Vietnam Dan chu Magazine, (Paris), $1997 \mathrm{nr}$ 12, s. 12.
}

26. Dien Dan Forum Magazine, 1996, nr 7.

\section{Florian Buks \\ WYBORY DO WLADZ LOKALNYCH TAJWANU}

Wybory do władz lokalnych na Wyspie, które odbyły się 29 listopada 1997 r. przyniosły zwycięstwo Demokratycznej Partii Rozwoju (DPP). Jest to wydarzenie bez precedensu, albowiem po raz pierwszy wygrała je partia opozycyjna, przełamując jednopartyjny monopol, wciąż trwający mimo dziesięcioletniego już okresu demokratyzacji. Wyniki wyborów są odzwierciedleniem nastroju jaki panuje od dłuższego czasu w społeczności tajwańskiej; narastające niezadowolenie z rządów Kuomintangu (KMT), pogarszająca się stopa życiowa warstwy średniej i najniżej zarabiającej, bogacenie się wysokich urzędników KMT, korupcja, wzrost przestępczości, obawy części społeczeństwa przed zjednoczeniem z kontynentem.

Najwięcej, bo 12 na 23 urzędy we władzach lokalnych zdobyła DPP. Kuomintang zwyciężył w 8 powiatach, co uważa się za wielką przegraną, niezależni zaś zdobyli 3 powiaty. Procentowo wyniki przedstawiają się następująco: $43,67 \%$ głosów na DPP, $42,1 \%$ na KMT.

$\mathrm{Z}$ pierwszych komentarzy wynika, że przegrana KMT jest zapowiedzią znaczacych zmian na Tajwanie. Wybory wykazały rosnąca dojrzałość 11-letniej DPP. Członkowie KMT domagają się rezygnacji prezydenta Lee Teng-hui z funkcji przewodniczącego KMT, zwłaszcza że sekretarz generalny KMT Wu Poh-hsiung podał się już do dymisji. Dymisja została przyjęta i na jego miejsce wybrano wicepremiera John'a Changa, do niedawna ministra spraw zagranicznych Tajwanu. Gubernator prowincji Tajwan James Soong nawołuje do reform $\mathrm{w}$ łonie KMT.

Giełda zareagowała na wynik wyborów spadkiem. Są głosy, że zwycięstwo DPP może stworzyć trudności w kontynuowaniu kontaktów przez Cieśninę (DPP optuje za niepodległością Tajwanu). Premier W. Siew ostrzega partie przed próbami konfrontacji i zapowiada zmiany w rządzie. Przeciwnicy DPP podnosza głosy, że zwycięstwo może w krótkim czasie zniszczyć rynek i gospodarkę Tajwanu. Natomiast minister P.K. Chiang, 